\title{
Developing Innovative Financing Scheme for Leveraging Energy Efficiency Deployment in Indonesia
}

\author{
Robi Kurniawan ${ }^{1}, *$, Irwan W. Kurniawan ${ }^{1}$ \\ ${ }^{1}$ Ministry of Energy and Mineral Resources, Jl. Medan Merdeka Selatan No. 18, DKI Jakarta 10110, Indonesia \\ *Corresponding Author: kurniawan.tohoku@gmail.com
}

\section{Article History}

Received 18 October 2021

Accepted 16 February 2022

Available 27 February 2022

\begin{abstract}
Having great potential, a mechanism that can leverage private involvement in energy efficiency deployment should be developed in emerging markets such as Indonesia. This study aimed to formulate an implementable financial innovative scheme for leveraging energy efficiency deployment in the country. Scrutinizing relevant studies and interviewing relevant stakeholders such as the Ministry of Finance, Ministry of Energy and the Financial Institution, we formulated a blended financial scheme for an energy efficiency project. Main stakeholders will include the scheme, including fund facilitator, trustee, custodian bank and energy user/energy service company. In our proposed scheme, Indonesia Environment Fund (IEF) is obtained the fund from the fund facilitator. IEF will act as a trustee that delivers funds for the Custodian Bank. The bank will disburse the fund to the feasible energy efficiency project or through an energy service company. In this scheme, since banks get lower interest rate funds from the trustee, they will disburse the fund to the customer with a lower interest rate than a commercial rate. Consumers utilize the fund for their energy efficiency projects. Utilizing a proposed scheme to an energy efficiency project case study, it is found that the proposed scheme potentially reduces the interest rate and leverages the project viability in a certain condition. Doing the sensitivity analysis by comparing interest rate and IRR (Internal Rate of Return) in several loan periods, we found that the shorter period of the loan and lower interest rate can improve projects feasibility. For instance, simulating a 5-year loan, it is found that reducing the interest rate from $12 \%$ to $7 \%$ could improve up to $2 \%$ IRR of the project case. Therefore, the scheme can catalyze private-sector investments mobilization for energy efficiency deployment in the country. Furthermore, it can support the country's energy security enhancement.
\end{abstract}

Keywords:

financial blending; energy efficiency; Indonesia Environment Fund; sustainable energy transition; energy security

\section{Introduction}

Energy efficiency is recognized as an important aspect of energy security and economic recovery. The measure is considered an effective strategy for improving energy security by minimizing energy demand and reducing dependence on energy imports (Trotta, 2020). Implementing the energy efficiency measure can reduce energy consumption and emission in sectoral case, such as in the building sector (Kurniawan \& Feinnudin, 2021). In addition, energy efficiency significantly increases energy security by improving environmental aspects such as emission mitigation and reducing local emission and reduction of local air pollutants (Selvakkumaran \& Limmeechokchai, 2013). Surveying central bank officials, government agencies and the economic experts of G20, it is found that clean energy infrastructure and energy efficiency are among the sector that can contribute to economic recovery and emission reduction targets (Hepburn et al., 2020). To achieve a sustainable recovery, there is a need to 
balance employment for the short term and mitigating climate change over the long term (Halimatussadiah et al., 2020). Doing so, energy efficiency project is typically a labor-intensive sector, investment in energy efficiency will create more than three-time compare to the fossil sector (GarrettPeltier, 2017).

Aligning energy security and cleaner energy transitions needs a crucial steep rise of finance and investment. From a global perspective, it is estimated that investment will increase significantly over the next decade. International Renewable Energy Agency (IRENA) estimates that USD 4.4 trillion is required to achieve carbon neutrality by 2050 (IRENA, 2021). A joint analysis of the International Monetary Fund and the International Energy Agency forecast around USD 5 trillion annual investment to the sector to achieve the agenda, as stipulated in the energy sector roadmap (IEA, 2021b). It increases more than double compared to the existing energy sector investments that are still below USD 2 trillion. This investment increasing is required across clean energy solutions such as renewable energy, smart resilience network, as well as energy efficiency project.

On the other hand, to achieve the climate target, the G7 groups, the world's seven largest developed economies, agreed to ban international financing for coal and related dirty fossil fuel projects that emit emissions by the end of 2021 (Wacket \& Markus, 2021). Therefore, there is a tendency of increasing risk for carbon-intensive projects and companies. Many asset managers, banks and financial institutions, for instance, Asian Developing Bank (ADB, 2021), have shifted to supporting low carbon transition projects.

The sustainable finance momentum is growing but still not distributed evenly, especially in emerging markets such as Indonesia. In particular group countries, emissions are increasing significantly while clean energy financing is still not mature yet (IEA, 2021a). By adopting massive energy efficiency, Indonesia can avoid building $25 \mathrm{GW}$ of the planned fossil power plants (McNeil et al., 2019) that negatively impact the environment (Aissa \& Hartono, 2016). Flourishing financing worldwide will not be absorbed optimally to climate-friendly investment such as efficiency projects with the condition.

Furthermore, energy efficiency has specific characteristics compared to the other infrastructures with better returns and quicker repayment. Financing support is necessary especially for upgrading the technology when the project owners do not have the capacity or are unwilling to pay the associated incremental cost for the project (USAID, 2021). Therefore, market interventions with energy efficiency project owners and lenders can help them overcome the financial barrier and enhancing the expansion of energy efficiency across sectors.

This massive opportunity and barrier require concerted policy interventions, public finance and financial institution initiatives to be realized to achieve the objective. In the face of limited public funding, increasing private-sector investment in energy efficiency financing will be crucial. A financial institution such as banking requires to step up its role as catalysts for investment.

In its underdeveloped stage, blending commercial lending is a solution for ramping up the implementation of energy efficiency projects (OECD, 2018). In the framework, funding and mechanisms from a financial institution such as a bank can be blended with another source such as grants, guarantees, technical assistance and concessional loans. However, although blending commercial is gaining importance in supporting energy security and achieving sustainable growth, there is currently no such specific study and application in Indonesia for energy efficiency deployment. Previous studies dealing with a framework such as (Mustapha \& Gavas, 2014) and (World Economic Forum, 2016) did not address an emerging market, especially for Indonesia case. The energy efficiency financial model faces several barriers in the country, such as limited funds and high transaction costs (Nurcahyanto et al., 2020).

From the backdrop, this study aimed to formulate the scheme for innovative sustainable financing for energy efficiency deployment by blending the public and commercial funds. Doing so, we conduct a 
literature review of financial blending, as presented in section two and perform in-depth interviews and discussions with key government agencies and related private stakeholders.

This study contributes to existing literature and empirical condition in several ways. First, understanding the activity that aligning sustainable recovery and energy security is a timely and important addition to climate change and energy policy study. Second, our study focuses on a country where the blending mechanism are rarely discussed. Dominated by fossil sources in their energy (Kurniawan et al., 2020; PYC, 2021), developing such a mechanism can leverage a cleaner energy transition in the country. Third, the study addresses the involvement private sector that can increase energy efficiency deployment in the developing country. Therefore, this study will become a significant input to the policymaker, researcher and the private sector.

\section{Blended Finance Overview}

A potential investor in the clean energy sector bears high financing costs related to the risk. The financial instruments that consist of several categories such as direct investments, revenue support, insurance and credit enhancement are well suited as a de-risking instrument (Torvanger et al., 2016). It is considered can reduce the market and commercial risk. Financial de-risking is intended to transfer the risks that private sectors face to the public actors such as public institutions and development banks (Waissbein et al., 2013). The financial instruments are rarely deployed in a single application, rather it is usually applied in blended combination instruments (W. Li et al., 2016). The de-risking tool can be classified into several forms such as preferential loans, subsidized loans, guaranteed loans and green bonds (Steckel \& Jakob, 2018).

Regarding environmental pollution, preferential loans, such as green loans, have attracted the stakeholder globally (Z. Li et al., 2018). Developing an attractive clean energy investment can be conducted by providing low-interest loans or access to a public loan with a specific interest. The loan scheme could trigger a private sector for investing in a relatively new business model by ensuring the proper return.

Blended finance is defined as "the strategic use of development finance for the mobilization of additional finance towards sustainable development in developing countries" (OECD DAC, 2017), as indicated in Figure 1. Development finance refers to financing to developing countries for supporting the development target such as grants and technical assistance. In the mentioned concept, additional finance is referred to as commercial finance. A particular fund currently might not be well aligned with sustainable development targets. It covers both public and private sources such as public or privately owned pension funds, insurance companies, banks and businesses.

From the definition, the finance aimed to fill the gap of sustainable development goal target by mobilizing commercial funding through public funding catalyzation, especially in developing countries. Blended finance also has specific objectives, such as improving projects viability due to its wide positive development impact but inadequate risk-adjusted financial returns, enhancing public spending, minimizing risk and enabling market (Mustapha \& Gavas, 2014). Furthermore, it is a mechanism to utilize the resource to achieve the outcome, attracting additional non-development financing, shifting from financing the private sector to mobilizing private finance and combining mobilization at the transaction level with a catalytic ambition over time (OECD, 2018).

Having half of infrastructure investment capacity globally, there are obstacles to unlocking private finance in developing countries, even though it offers better returns (Bielenberg et al., 2016). Among the barriers are lacking bankable pipeline, high transaction cost, as well as lack of viable investment model. The blended feature may address the risk-return profiles of funding in developing nations as well as attracting a commercial investor. It is found that blended finance investment has been attracted up to 20 times of the amount capital from the private sector (World Economic Forum, 2016). It can collaborate with diverse actors, from public to private by leveraging its strength, to solve the barrier of 
investment in the countries. Among the public sector, strengths bring trust and an embedded task to help those most in need. On the private side, it has network, innovation, result-driven and risk-taking.

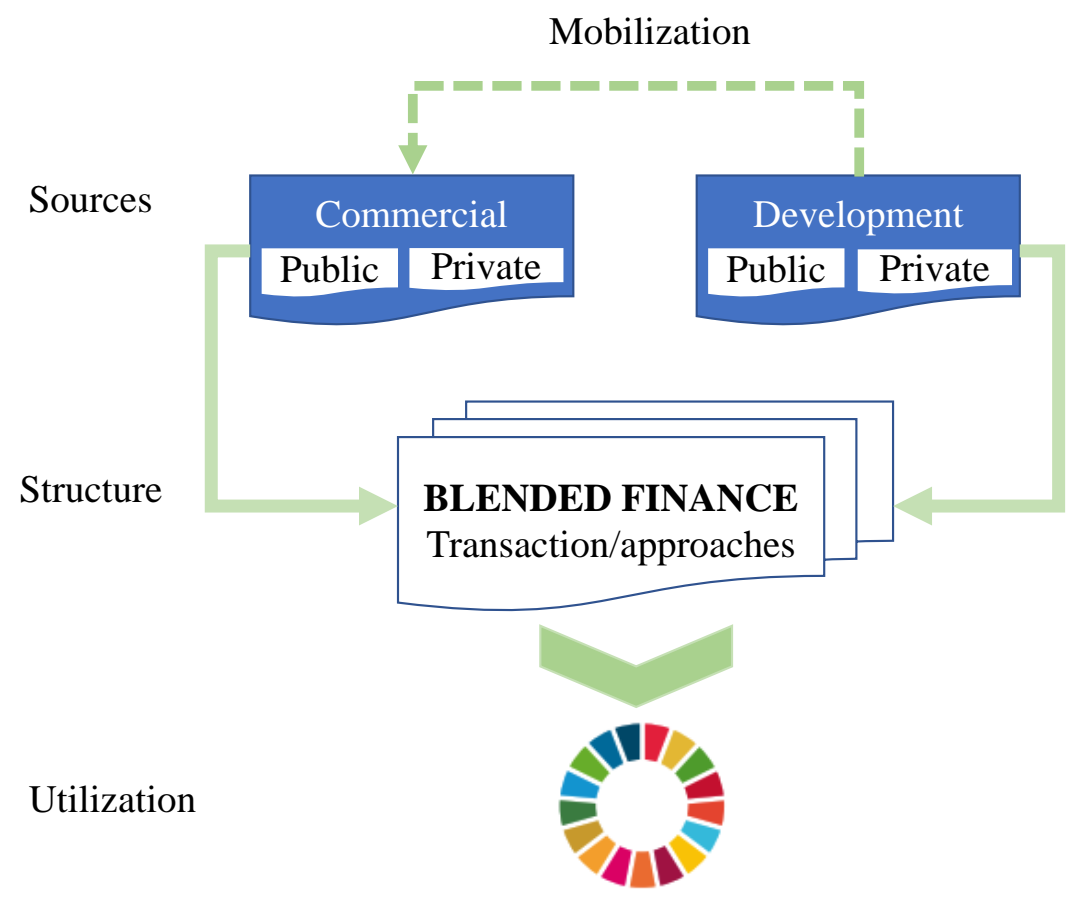

Sustainable development goals

Figure 1. Blended financing framework (OECD, 2018).

For achieving blended finance, three elements should be incorporated: government and bilateral aid agencies, public sector operations/multilateral development banks and specialized private sectororiented development financial institutions (OECD, 2018). Grant and other concessional fundings are provided by the government and aid agencies. Financing and managing are provided by public sector operations and multilateral development banks. Instrument deployment and scheme structurization becoming the crucial role of the specific private sector-oriented development finance institutions.

It is found that five different instruments have been employed for this scheme, including guarantees, credit lines, direct investment in companies, shares in common investment vehicles/ funds and syndicated loans (Benn \& Hos, 2017). It is also utilized across the sector, such as banking, finance, industry transport, agriculture, the health sector and the energy service industry. The energy service industry is principally one of the key solutions for generating green jobs and managing finance. Energy Services Company (ESCO) offers guaranteed energy savings, implementation, maintenance for a client in the public or private sector (Zheng et al., 2021). The types of investees that blended finance can target cover companies, financial institutions, projects, portfolios and governments.

\section{Method}

For formulating a blending financing scheme, we conducted a literature review of financial blending such as the OECD framework (OECD, 2018), scrutinize available policy and options, and relevant information. In-depth interviews and discussions are conducted with key government agencies and related private stakeholders such as the Ministry of Energy, Ministry of Finance, Commercial Banks, Energy Service Company Association (APKENINDO) and private sector businesses. Furthermore, we had to exercise a case of IGA (Investment Grade Audit) funded by the government for an office building in Jakarta. A certified energy auditor had conducted a specific baseline measurement for the lighting system. Then a financial model with several scenarios had been simulated for the case study. 


\section{Result and Discussion}

Several primary stakeholders will include the blending scheme, fund facilitator, trustee, custodian bank, and energy user/energy service company. The Indonesia Environment Fund (IEF) that the Ministry of Finance recently established is proposed as a trustee. IEF is a public service agency (Badan Layanan Umum or BLU), a non-structural entity under the Ministry of Finance. Initially, it is aimed to manage funds for environmental protection and management. The public service agency offers several advantages. IEF can deliver the fund to climate change mitigation and adaptation efforts, which also can include energy efficiency projects. IEF also offers flexibility in terms of the sources of funds and its instruments. It could have diverse sources of funding, including international donors and carbon markets. Therefore, IEF can act strategically as a hub for various funding mechanisms for different portfolios that also cover energy efficiency.

Financial institutions, in this case, custodian banks, are involved in the scheme due to their wide operational network. Moreover, it has a list of potential customers that potentially interested in the energy efficiency project. Having expertise in lending, the risk of default can be minimized and shifted from trustee to the bank. In the scheme, the loan can be accessed by small and medium-scale investments. Debt period can be provided up to certain years range with under commercial interest rate. Eligible energy efficiency objects can access the low-interest fund. Referring to Concerning the receiver of the fund as stipulated in Government Regulation No. 70 of 2009, several groups can obtain the funding. The first group is an entity that consumes equal or more than 6000-ton oil equivalent, successfully implementing energy efficiency measures at certain periods. The second group is the producer of energy-saving that conducted energy conservation. Another group that can access the data is the energy service company. Another potential market segments are a company that already received IGA facilitated by the government.

The scheme of blending the public and commercial funds for energy efficiency deployment is presented in Figure 2. Indonesia Environment Fund has obtained the fund from the fund facilitator. It can be grants, guarantees, technical assistance and concessional loans. IEF will act as a trustee that delivering funds for the Custodian Bank. The bank will disburse the fund to the feasible energy efficiency project or through an energy service company. In this scheme, since banks get lower interest rate funds from the trustee, it will disburse the found to the customer with a lower interest rate compared to a commercial rate. Consumers utilize the fund for their energy efficiency projects. Using this scheme, still, there are collateral and another project mechanism appraisal as stipulated in banking regulation.

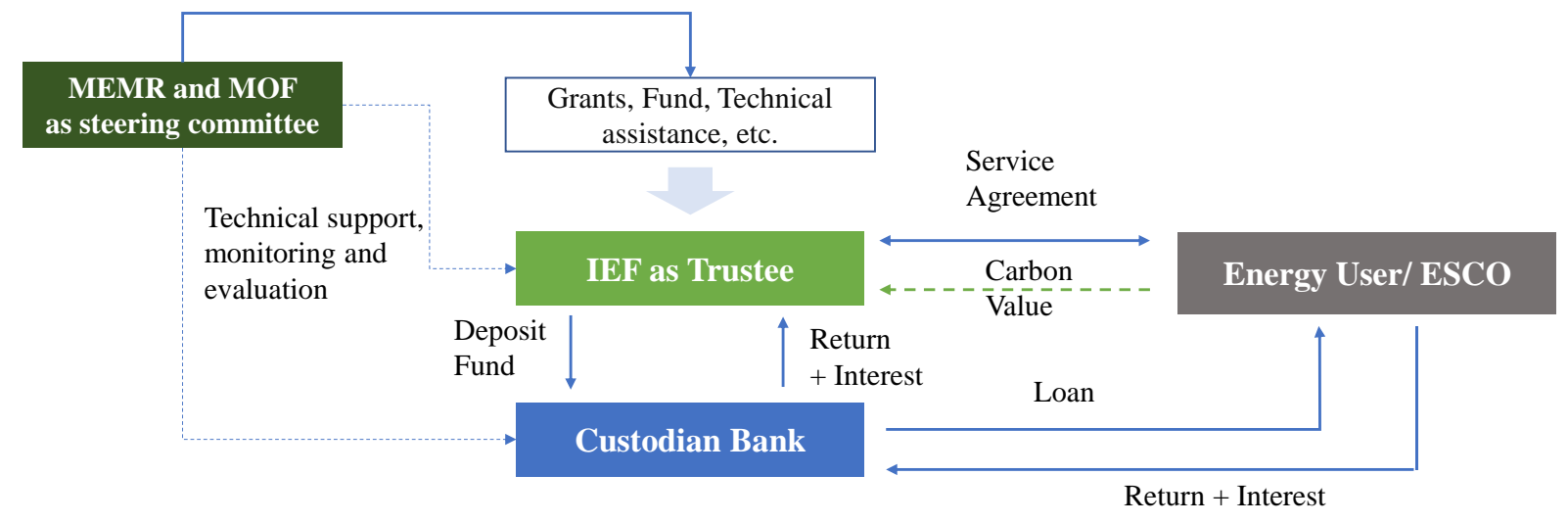

Figure 2. Financial blending proposed concept scheme.

To access the fund, initially, the project owner has to conduct a feasibility study by implementing an energy or investment-grade audit. It can be performed by internal resources or by hiring an energy service company. The main aspects of the feasibility study are to measure energy-saving potential, checking the project technically and assessing the financial aspect including payback period, internal 
rate of return and the net present value of the project. Having a feasible energy efficiency project, the owner will apply to the bank. Bank will check the proposals by performing the financial and technical assessment, perform a financial feasibility analysis and technical feasibility analysis of the project. If the energy efficiency project is feasible, then the bank will proceed with the application.

The fund is disbursed to a certain project that copes with the technical guidance. Certain energy efficiency projects, especially in the industrial and building sector, can be covered in the scheme. In the industrial sector, it can cover both in supply and demand sides. The supply side includes activity for improving the efficiency of generation or energy conversion. It includes waste heat generation reduction, waste heat recovery, cogeneration, control system, as well as equipment utilization with efficient technology such as electric motors, steams turbines and boiler. On the demand side, it can cover the equipment that continuing operated over the long term such as motors, boilers, pumps, furnaces, lighting, industrial dryers, pumps, compressors and air conditioning systems. The scheme can be accessed for several technologies such as lighting, air conditioning, energy-saving equipment, machines and control systems in the building sector.

\section{Case study}

We had exercised a case of IGA funded by the government for an office building in Jakarta, a specific baseline measurement for lighting system had been conducted by International Performance Measurement and Verification Protocol (IPMVP) certified auditor, the recommendation of IGA may impact in the reduction of electricity bill in lighting around $60 \%$. Thus, we simulate a financial model in several scenarios on a fixed parameter as seen in Table 1.

Table 1. Financial model of case study.

\begin{tabular}{|c|c|c|c|}
\hline CAPEX + OPEX & Value & Revenue & Value \\
\hline $\begin{array}{l}\text { Investment in lighting } \\
\text { retrofit }\end{array}$ & USD 160,000 & \multirow{8}{*}{$\begin{array}{l}\text { Electricity bill } \\
\text { saving on a lighting } \\
\text { retrofit }\end{array}$} & \multirow{8}{*}{$\begin{array}{l}\text { Baseline cost } \\
\text { calculated cost after } \\
\text { retrofit = } 60 \% \\
\text { saving }\end{array}$} \\
\hline Project Management, & $17 \%$ of Investment & & \\
\hline $\begin{array}{l}\text { Installation, Lifecycle } \\
\text { Service }\end{array}$ & & & \\
\hline Debt / Equity & $70 \% / 30 \%$ & & \\
\hline Depreciation period & $\begin{array}{l}9.6 \text { years (calculated } \\
\text { from } 30,000 \text { hours of an }\end{array}$ & & \\
\hline & $\begin{array}{l}\text { LED lifetime and } \\
\text { average light hour) }\end{array}$ & & \\
\hline Pre-Op & $2.5 \%$ of CAPEX & & \\
\hline OPEX & $7 \%$ from Revenue & & \\
\hline
\end{tabular}

Table 2 illustrated the loan and interest rate simulation. The darker value means the project should be avoided due to the value of NPV is negative and Profitability Index is less than 1. The table indicates the project feasibility, as well as capturing our proposed scheme. The sensitivity analysis is by comparing bank's interest rate and IRR in several loan periods, our finding is the longer period of the loan and higher interest rate, then the project is not feasible. For instance, simulating a 5-year loan, it is found that reducing the interest rate from $12 \%$ to $7 \%$ could improve up to $2 \%$ IRR of the project case. IEF should come to the table as a trustee to reduce the bank's interest rate as well as leverage the project viability in a certain condition.

Furthermore, the energy efficiency project must be a short period of the loan, high saving potential, low hanging fruit project and verified by measurement and verification to reduce the financial and technical risks. Energy efficiency technology, such as improving air conditioning systems, boiler systems and lighting systems, generally have eligible payback periods between three to five years. Energy efficiency projects with a shorter payback are normally given priority. A short payback in the project means the 
measure achieves high savings relative to its cost, delivering more return per investment spent upfront. It will also deliver the investment they save become available sooner.

Table 2. Loan and interest rate simulation.

\begin{tabular}{rrrrrrr}
\hline $\begin{array}{c}\text { Loan } \\
\text { Period } \\
\text { Interest }\end{array}$ & $\begin{array}{c}\text { 4 Year } \\
\text { Loan }\end{array}$ & $\begin{array}{c}\text { 5 Year } \\
\text { Loan }\end{array}$ & \multicolumn{1}{c}{$\begin{array}{c}\text { 6 Year } \\
\text { Loan }\end{array}$} & $\begin{array}{c}\text { 7 Year } \\
\text { Loan }\end{array}$ & $\begin{array}{c}\text { 8 Year } \\
\text { Loan }\end{array}$ & $\begin{array}{c}\text { 9 Year } \\
\text { Loan }\end{array}$ \\
\cline { 2 - 7 } Rate $\%)$ & IRR (\%) & IRR (\%) & \multicolumn{1}{c}{ IRR (\%) } & IRR (\%) & IRR (\%) & IRR (\%) \\
\hline 7.0 & 10.70 & 10.30 & 9.91 & 9.54 & 9.17 & 8.82 \\
7.5 & 10.53 & 10.10 & 9.68 & 9.28 & 8.80 & 8.50 \\
8.0 & 10.36 & 9.90 & 9.45 & 9.01 & 8.59 & 8.17 \\
8.5 & 10.19 & 9.70 & 9.22 & 8.75 & 8.29 & 7.84 \\
9.0 & 10.02 & 9.50 & 8.99 & 8.49 & 8.00 & 7.51 \\
9.5 & 9.89 & 9.30 & 8.75 & 8.22 & 7.70 & 7.18 \\
10.0 & 9.68 & 9.10 & 8.52 & 7.96 & 7.40 & 6.84 \\
10.5 & 9.52 & 8.90 & 8.29 & 7.70 & 7.10 & 6.51 \\
11.0 & 9.36 & 8.70 & 8.06 & 7.43 & 6.80 & 6.17 \\
11.5 & 9.18 & 8.50 & 7.83 & 7.16 & 6.50 & 5.83 \\
12.0 & 9.01 & 8.30 & 7.60 & 6.90 & 6.20 & 5.48 \\
12.5 & 8.85 & 8.10 & 7.36 & 6.63 & 5.89 & 5.14 \\
13.0 & 8.68 & 7.90 & 7.13 & 6.36 & 5.59 & 4.79 \\
13.5 & 8.51 & 7.70 & 6.90 & 6.10 & 5.28 & 4.44 \\
14.0 & 8.35 & 7.50 & 6.67 & 5.83 & 4.97 & 4.09 \\
14.5 & 8.18 & 7.31 & 6.44 & 5.56 & 4.66 & 3.73 \\
\hline
\end{tabular}

As a comparison with the proposed scheme, Indonesia Environment Fund delivered investment to reforestation (IEF, 2021). Accordingly, it can directly deliver the fund to the debtor for usaha kehutanan (forestry-related effort such as reforestation project) with $0-8 \%$ interest rate and environmental investment with 0-9\% rate annually. In other scenarios, the funds will be placed through the financial institution before it distributes to the project with an interest rate of around 1-4\% annually. Further, the institution will lend the fund to the projects at a certain interest rate.

\section{Conclusion and Recommendation}

Blended finance can be particularly important for supporting energy-efficiency projects in emerging countries such as Indonesia. Scrutinizing relevant regulations and options as well as interviewing selected stakeholders, we formulated a financial blended scheme for an energy efficiency project. Main stakeholders will include the scheme, including fund facilitator, trustee, custodian bank and energy user/energy service company.

The Indonesia Environment Fund, a non-structural entity under the Ministry of Finance, that was initially developed to manage funds for environmental protection and management is proposed as a trustee. Utilizing the scheme with IEF as a trustee potentially can reduce the bank's interest rate as well as leverage the project viability in a certain condition as shown by our simulation case. Utilizing blended finance, which blends commercial lending with grants, concessional finance, development funds and technical assistance, can help leverage private investment and finance projects in riskier markets and sectors such as energy efficiency projects. The scheme can catalyze private-sector investments mobilization.

To implement the scheme, several steps are needed to be performed. Further institutional arrangements and the source of funds of the trustee need to be clarified. Detail discussion with financial institutions especially potential custodian banks should be conducted. Feedback from the financial institution is crucial since the will have a primary role. Points for discussion among others are rate from trustee, disbursement, loan period, as well as the amount of eligible loan. Furthermore, technical assistance for 
the preparation of detailed energy efficiency projects can help fill the gap in identifying and developing bankable projects. Capacity-building to financial institutions could also be provided as part of technical assistance to help them identify the energy efficiency projects.

This study has several issues that could be addressed in future research. Further elaborations, such as the implementation of the financing scheme for supporting local government in emission reduction projects, as well as considering a specific project such as a street lighting financing scheme, would enhance our understanding of sustainable innovative financing for developing countries.

\section{References}

ADB. (2021). Energy policy: Supporting low carbon transition in Asia and the Pacific. ADB.

Aissa, N., \& Hartono, D. (2016). The impact of geothermal energy sector development on electricity sector in Indonesia economy. Buletin Ekonomi Moneter Dan Perbankan, 19(2), 153-176.

Benn, C. S., \& Hos, T. (2017). Amounts mobilised from the private sector by Official Development Finance interventions: Guarantees, syndicated loans, shares in collective investment vehicles, direct investment in companies, credit lines. OECD Development Co-Operation Working Papers, 36.

Bielenberg, A., Kerlin, M., Oppenheim, J., \& Roberts, M. (2016). Financing change: How to mobilize private-sector financing for sustainable infrastructure. McKinsey Center for Business and Environment, 24-25.

Garrett-Peltier, H. (2017). Green versus brown: Comparing the employment impacts of energy efficiency, renewable energy, and fossil fuels using an input-output model. Economic Modelling, $61,439-447$.

Halimatussadiah, A., Widyasanti, A. A., Damayanti, A., Verico, K., Qibthiyyah, R. M., Kurniawan, R., Rezki, J. F., Rahardi, F., Sholihah, N. K., Budiantoro, S., Halimatussadiah, A., Cesarina, A., Siregar, A. A., Hanum, C., Wisana, D., Rahardi, F., Bintara, H., Rezki, J. F., Husna, M., ... Sofiyandi, Y. (2020). Thinking ahead: Indonesia's agenda on sustainable recovery from COVID -19 pandemic. LPEM.

Hepburn, C., O'Callaghan, B., Stern, N., Stiglitz, J., \& Zenghelis, D. (2020). Will COVID-19 fiscal recovery packages accelerate or retard progress on climate change? Oxford Review of Economic Policy, 36.

IEA. (2021a). It's time to make clean energy investment in emerging and developing economies a top global priority. IEA.

IEA. (2021b). Net zero by 2050. A roadmap for the global energy sector. IEA

IEF. (2021). Fund management by IEF and strategic plant development. IEF.

IRENA. (2021). World Energy Transitions Outlook. IRENA

Kurniawan, R., \& Feinnudin, A. (2021). Assessing the Implementation of the Energy Management System in the First ISO 50001 Building in Indonesia. Indonesian Journal of Energy, 4(2), 129139.

Kurniawan, R., Trencher, G. P., Edianto, A. S., Setiawan, I. E., \& Matsubae, K. (2020). Understanding the multi-faceted drivers of increasing coal consumption in Indonesia. Energies, 13(14), 1-22. https://doi.org/10.3390/en13143660

Li, W., Nguyen, Q. T., \& Narayanaswamy, M. (2016). How banks can seize opportunities in climate and green investment. International Finance Corporation. https://doi.org/10.1596/30353

Li, Z., Liao, G., Wang, Z., \& Huang, Z. (2018). Green loan and subsidy for promoting clean production innovation. Journal of Cleaner Production, 187, 421-431.

McNeil, M. A., Karali, N., \& Letschert, V. (2019). Forecasting Indonesia's electricity load through 2030 and peak demand reductions from appliance and lighting efficiency. Energy for Sustainable Development, 49, 65-77.

Mustapha, A. P., \& Gavas, M. (2014). Blended finance for infrastructure and low-carbon development.

Nurcahyanto, Simsek, Y., \& Urmee, T. (2020). Opportunities and challenges of energy service companies to promote energy efficiency programs in Indonesia. Energy, 205, 117603. https://doi.org/10.1016/j.energy.2020.117603 
OECD. (2018). Making blended finance work for the sustainable development goals. OECD Publishing. https://doi.org/10.1787/9789264288768-en

OECD DAC. (2017). Blended finance principles for unlocking commercial pinance for the SDGs", Annex to the DAC High Level Communique of 31 October 2017. OECD.

PYC. (2021). Primary Energy Supply. PYC

Selvakkumaran, S., \& Limmeechokchai, B. (2013). Energy security and co-benefits of energy efficiency improvement in three Asian countries. Renewable and Sustainable Energy Reviews, 20, 491-503.

Steckel, J. C., \& Jakob, M. (2018). The role of financing cost and de-risking strategies for clean energy investment. International Economics, 155, 19-28.

Torvanger, A., Narbel, P., Pillay, K., \& Clapp, C. (2016). Instruments to incentivize private climate finance for developing countries. CICERO. https://cicero.oslo.no/en/publications/internal/2836

Trotta, G. (2020). Assessing energy efficiency improvements and related energy security and climate benefits in Finland: An ex post multi-sectoral decomposition analysis. Energy Economics, 86, 104640.

USAID. (2021). Overcoming barriers to energy efficiency financing. USAID

Wacket, E., \& Markus, P. (2021). In climate push, G7 agrees to stop international funding for coal. Reuters.

Waissbein, O., Glemarec, Y., Bayraktar, H., \& Schmidt, T. (2013). Derisking renewable energy investment. A framework to support policymakers in selecting public instruments to promote renewable energy investment in developing countries. United Nations Development Programme, $1-156$.

World Economic Forum. (2016). Insights from blended finance investment vehicles \& facilities, redesigning development finance initiative.

Zheng, S., Wang, R., Mak, T. M. W., Hsu, S.-C., \& Tsang, D. C. W. (2021). How energy service companies moderate the impact of industrialization and urbanization on carbon emissions in China? Science of The Total Environment, 751, 141610. 